\title{
Kroniskt trötthetssyndrom, fibromyalgi och risken att bli stigmatiserad
}

\author{
ANNA-LIISA NÄRVÄNEN \& PIA ÅSBRING \\ 25 kvinnor med kroniskt trötthetssyndrom respektive \\ fibromyalgi har intervjuats i syfte att undersöka om de \\ upplever att sjukdomarna kan vara stigmatiserande för \\ dem. Stigma beskrevs i synnerhet förekomma före det att \\ diagnosen fastställts och vara relaterad till den osäkerhet \\ som sjukdomarna är förknippade med.
}

\section{Introduktion}

Forskning om erfarenheter av kroniska sjukdomar är angeläget på grund av sådana konsekvenser de har för den som drabbas, bl.a. vad gäller en individs självuppfattning. En möjlig konsekvens är stigmatisering. Forskning om stigmatisering kring olika sjukdomstillstånd har därför markant ökat under det senaste decenniet (Link \& Phelan, 2001). Denna artikel bygger på en intervjustudie med kvinnor

Anna Liisa Närvänen är lektor i sahälls- och kulturanalys vid Institutionen för Tematisk Utbildning och Forskning (ITUF) samt vid Tema äldre och åldrande, Linköpings universitet.

Pia Åsbring arbetar med forsknings- och utvecklingsarbete vid Enheten för Psykisk Hälsa inom Samhällsmedicin, Stockholms läns landsting. som har diagnosen kroniskt trötthetssyndrom (KTS) eller fibromyalgi. I artikeln fokuseras frågan om dessa sjukdomar är stigmatiserande samt vilka strategier kvinnorna utvecklar för att minska risken för stigmatisering (jfr Åsbring \& Närvänen, 2002).

Ett fåtal tidigare studier har relevans för diskussionen om stigmatisering i förhållande till KTS och fibromyalgi (Cooper 1997, Gullacksen, 1998, Hellström et al., 1999, Henriksson, 1995, Johansson et al., 1996, Söderberg, 1999, Ware 1992). Frågan om KTS och fibromyalgi är potentiellt stigmatiserande är dock inte systematiskt studerat i tidigare forskning, eller sådana strategier som patienter kan utveckla för att minska risken för stigmatisering. 


\section{Bakgrund}

Det som framför allt utmärker KTS och fibromyalgi är att båda kännetecknas av osäkerhet gällande diagnosticering, verifiering, etiologi och behandling, vilket kan öka stigmatiseringspotentialen för sjukdomarna. En sjukdom som inte är avgränsad till något specifikt organ, inte på ett objektivt sätt kan diagnosticeras och är svårbehandlad har ofta en låg status bland läkare (Album, 1991), vilket också kan påverka vårdgivaren i mötet med patienten. $\AA$ andra sidan har diagnoserna nu existerat en tid, diskuterats i medier och är föremål för medicinsk forskning, och kan därför tänkas ha blivit mer accepterade som legitima diagnoser, vilket kan minska stigmatiseringspotentialen.

KTS och fibromyalgi har delvis överlappande symtombilder (Nørregaard et al., 1993). Båda är s.k. kriteriediagnoser. Diagnosen KTS innefattar bl.a. trötthet och uttröttbarhet, muskelsmärta, muskelsvaghet, halsont, feber, huvudvärk, försämrat minne, koncentrationssvårigheter samt sömnstörningar (Evengård et al., 1999, Fukuda et al., 1994, Komaroff, 1994). Diagnosen fibromyalgi innefattar symtom såsom värk, smärta, stelhet och kraftlöshet i muskulaturen samt trötthet, uttröttbarhet, huvudvärk, svullnad, domningar, tarmproblem och sömnsvårigheter (Olin, 1995, Wolfe et al., 1990). Båda sjukdomarna drabbar i högre grad kvinnor än män (Komaroff, 1994, Olin, 1995).

Tidigare forskning som finns kring fibromyalgi och närbesläktade muskuloskeletala smärttillstånd belyser vissa aspekter som har betydelse för stigmatisering. Framför allt upplever patienterna att de ifrågasätts av vårdgivare (Gullacksen, 1998, Hellström et al., 1999, Henriksson, 1995, Johansson et al., 1996, Söderberg, 1999). Ware (1992) har bl.a. belyst att patienter med KTS upplever att deras besvär trivialiseras eller tillskrivs en psykosomatisk orsaksgrund, vilket betyder en delegitimering av besvären (jfr. även Cooper 1997).

Den tidigare forskningen saknar dock ofta analyser av sådana strategier som patienterna uppfattar sig utveckla för att hantera situationen i det sociala samspelet med andra. Ett undantag är Ware' s forskning (1992, 1998) som kort beskriver patienters strategier att undvika negativa stereotypier och stigmatisering.

Till skillnad från de ovannämnda studierna används i det föreliggande arbetet en specifik begreppsapparat, som introducerats av Goffman (1971), i högre utsträckning. Styrkan med denna begreppsapparat är att den möjliggör en nyanserad analys av stigmatisering (Link \& Phelan, 2001). Det teoretiska tänkandet presenteras nedan.

\section{Stigma och stigmatisering}

Med stigma avses här egenskaper som definieras av andra som djupt diskrediterande hos en individ, såsom fysiska missbildningar och psykisk sjukdom. Stigma kan också referera till ett visst socialt kollektiv som av andra betraktas med negativa kännetecken (Goffman 1971). Det är viktigt att notera att stigma handlar om relationen mellan egenskaper som av andra kan betraktas som diskrediterande hos en individ eller en grupp, och negativa stereotyperingar som är kopplade till dessa egenskaper (När- 
vänen, 1994, Link \& Phelan, 2001). Stigmatisering av en individ kan m.a.o. förstås som en process som sker i interaktion med andra och i vilken tillskrivna identiteter som är kopplade till negativa stereotyperingar är en viktig grund. Fullständig stigmatisering är ett faktum först om en individ inkorporerar den negativt tillskrivna identiteten i sin egen självuppfattning (Jenkins, 2000). Detta innebär att det också kan uppstå en diskrepans mellan en individs självuppfattning å ena sidan och identiteter som tillskrivs henne av andra å den andra (Goffman, 1971, Jenkins, 2000, Link \& Phelan, 2001, Närvänen, 1994). Vårdgivare, exempelvis, kan tillskriva patienter en diskrediterad identitet som simulant eller psykiskt sjuk om patienten inte har några yttre tecken på sjukdom och proverna inte visar något avvikande värde (Charmaz, 1983, Coyle, 1999), samtidigt som patienten upplever sig som fysiskt sjuk. Enligt tidigare forskning beror patienters missnöje med vårdgivare ofta på att vårdgivare har agerat på ett sådant sätt som hotar patienters självuppfattning. Att bli nedvärderad, avhumaniserad, objektifierad, stereotypifierad och fråntagen sin handlingsförmåga har beskrivits av patienter i dessa studier (Coyle, 1999), vilket kan tolkas i termer av stigmatisering.

Resonemanget innebär inte att alla sjukdomar är stigmatiserande. Stigmatisering är inte en nödvändig eller självklar konsekvens av sådana sjukdomar som kan vara potentiellt stigmatiserande. Distinktionen mellan att vara diskrediterad eller diskreditabel är därför viktig i diskussionen om stigma. En person kan vara diskrediterad, vilket innebär att hon har en synlig eller känd avvikelse och då tar för givet att det som gör att hon skiljer sig från andra är uppenbart. Att vara diskreditabel innebär att ha en avvikelse/egenskap som inte är direkt synlig eller känd för andra (Goffman, 1971, Åsbring \& Närvänen, 2002). Vid avslöjandet om den aktuella sjukdomen finns då en risk för att bli diskrediterad. Man måste alltså också skilja mellan verkliga stigmatiserande händelser som inträffat, dvs. iscensatt stigma och upplevt stigma. Den senare härrör sig från den skamkänsla som hör samman med en rädsla för att bli utsatt för iscensatt stigma (Scambler, 1984). Eftersom stigmatisering är en process som sker i interaktion med andra, kan en individ också skapa strategier för att undvika stigmatisering. En diskreditabel person kan exempelvis dölja information om det potentiellt stigmatiserande från andra, och därigenom skapa en sluten, eller begränsad medvetenhetskontext om sin belägenhet för att undvika avslöjandet (Närvänen, 1994).

Kroniska sjukdomar kan ha olika potential för stigma, eller olika grader av stigma, beroende på sjukdomarnas karaktär och till vilka - om några - negativa stereotyperingar sjukdomen kopplas (Link \& Phelan, 2001). Sjukdomens stigmatiseringspotential varierar beroende på sociala och kulturella föreställningar om den och vilka synliga tecken som är förknippade med den. Vissa sjukdomar är förknippade med skam, såsom epilepsi, pga anfallet, liksom HIV/AIDS som kan betraktas som skamfylld, socialt oacceptabel och dessutom smittsam. Fysiska missbildningar och handikapp kan vara synliga och uppenbara utåt, såsom blindhet, benmärgsbrock eller halvsidesförlamning som en konsekvens av 
stroke. Det som gör KTS och fibromyalgi särskilt intressanta för en studie om deras potential för stigma är sjukdomarnas specifika karaktär. Ingen av de egenskaper som uppenbart kan vara stigmatiserande kan förknippas med KTS och fibromyalgi. De är inte förknippade med skam och har inte några synliga tecken utåt. De frågor som undersöks här är om dessa sjukdomar är potentiellt stigmatiserande och vilka strategier patienterna i så fall kan skapa för att undvika risken för stigmatisering.

\section{Metod}

Studiens syfte är att söka kunskap om patienters erfarenheter av att leva med KTS och fibromyalgi. Utgångspunkten är alltså ett s.k. inifrån perspektiv, som sätter patienters erfarenheter i fokus (Conrad, 1987, Åsbring 2003).

Kvalitativa intervjuer valdes som datainsamlingsmetod. Intervjuerna har utförts i samtalsliknande former för att fånga kvinnornas uppfattningar om sin situation.

De tematiker som tagits upp under intervjuerna är kvinnornas uppfattningar om sin sjukdom, erfarenheter av möten med vårdgivare, strategier att hantera sin situation med sjukdomen, och hur de uppfattat att andra människor bemöter dem i olika sammanhang. Intervjuerna utfördes under perioden 1995-1998, varierade mellan 60150 minuter, bandinspelades och transkriberades ordagrant.

Studien omfattar intervjuer med totalt 25 kvinnor, varav 12 har diagnosen KTS och 13 fibromyalgi. Kvinnorna valdes ut i samverkan med två olika vårdenheter som hade specifika program för dessa patientgrupper.
För urval gavs ett antal kriterier i syfte att uppnå en variation bland de intervjuade, avseende ålder, yrke, utbildningsnivå och hur länge personen i fråga hade haft sjukdomen. Åldern varierade mellan 32-65 år, och sjukdomstiden från 1-23 år. Majoriteten av de intervjuade var sjukskrivna eller hade sjukpension. Ett fåtal var yrkesverksamma.

Forskningsetiska principer om konfidentialitet och informerat samtycke har genomgående följts i studien. Ett problem i sammanhanget skulle i princip kunnat vara urvalsförfarandet, d.v.s. att kvinnorna tillfrågades av vårdgivare om deltagandet $\mathrm{i}$ studien. Eftersom patienterna kan känna sig beroende av god vilja från vårdgivare skulle detta kunnat innebära att även personer som inte ville medverka gav sitt medgivande. För att minska den risken informerades och tillfrågades samtliga ytterligare en gång av forskaren som gjorde intervjun.

I datainsamling och i dataanalys har grounded theory procedurer använts (Glaser \& Strauss, 1967, Strauss \& Corbin, 1990). Till skillnad från tidiga tankegångar om grounded theory (Glaser \& Strauss, 1967), har i detta arbete också tidigare utvecklade teoretiska begrepp använts, vilket dock enligt den modifierade versionen av grounded theory (Strauss \& Corbin, 1990) är fullt acceptabelt om begreppen kan grundas i de data som analyseras.

Preliminär analys har gjorts efter varje intervju, vilket har varit vägledande både för fortsatta intervjuer och för urvalets storlek. Analysprocessen omfattar olika faser: upprepade genomläsningar av intervjuer; sortering av intervjuutsagorna i centrala tematiker; kontinuerlig modifiering och specificering av tematiker/kategorier 
under databearbetning; konstant komparation (Glaser \& Strauss, 1967, Strauss \& Corbin, 1990).

I denna artikel redogörs enbart för de resultat som handlar om patienters beskrivningar av stigmatisering. De kategorier som redogörs för nedan handlar om trovärdighet och moral, psykologisering av orsaken till sjukdomen, och om diagnosens betydelse. Vidare redogörs för kvinnors strategier att hantera sådana situationer som de uppfattar som potentiellt stigmatiserande.

Eftersom studien är tämligen liten görs här inga anspråk på statistisk representativitet. Studiens resultat kan heller inte generaliseras med någon säkerhet till en större population. Som vi diskuterar i slutet av artikeln, finns det dock ett antal andra studier som visar likartade resultat som den föreliggande, vilket i viss mån bekräftar vår studie. I analysarbetet har dessutom båda författarna, med delvis olika vetenskapliga bakgrunder och därmed olika förförståelse för fenomenet i fråga, medverkat vilket har varit en styrka i den slutgiltiga analysen och tolkningen av materialet.

\section{Resultat}

Två typer av reaktioner från andra människor i kvinnornas sociala omgivning har i intervjusvaren beskrivits som särskilt viktiga i förhållande till stigmatisering, nämligen ett ifrågasättande av kvinnornas moraliska karaktär och psykologisering av deras besvär. Också diagnosens benämning och karaktär har viss betydelse i sammanhanget. Förutom dessa, redogörs också för de strategier kvinnorna beskrivit att de använt sig av för att minska risken för stig- matisering. Dessa omfattar huvudsakligen ett undandragande från andra och informationsstyrning.

\section{Ett ifrågasättande av den moraliska karaktären}

Ett tydligt mönster i intervjusvaren är kvinnornas beskrivningar av att sanningshalten i deras sjukdomserfarenheter har blivit ifrågasatt av andra, vilket upplevs som djupt kränkande. Detta beskrivs i termer av en motsättning mellan ens självuppfattning och hur man blir definierad av andra, vilket utgör ett hot mot identiteten. I citatet nedan beskrivs en motsättning mellan den egna moraliska övertygelsen om hur man är som människa och andras ifrågasättande av denna, vilket kan upplevas som en större belastning än sjukdomen i sig.

Jag är superärlig och uppriktig människa altså och jag är stenhårt uppfostrad att inte ljuga, att inte luras, att inte stjäla, att inte göra fel saker. Jag har haft en väldigt moralisk familj överhuvudtaget och så fär man höra sådant att man, ja att man inte blir trodd va, det är så jobbigt så att det har nästan varit det värsta. Det har varit värre än smärtorna faktiskt. (FM)

Avsaknaden av yttre synbara tecken på sjukdom beskrivs av kvinnorna som en orsak till ifrågasättandet av deras tillstånd. Många tror att tydliga yttre tecken på sjukdom skulle kunnat öka deras trovärdighet. Ifrågasättandet har framför allt inträffat före det att kvinnorna erhållit en diagnos. I synnerhet har läkarna ifrågasatt deras trovärdighet efter det att provtagningar och 
andra undersökningar inte visat något patologiskt fel. En vanlig beskrivning är att läkaren har varit positivt inställd till kvinnan och hennes problem före det att provresultat erhållits, men att han/hon ändrat attityd efter det att negativa provsvar erhållits, och uttryckt misstänksamhet. Misstänksamhet uttrycks, enligt intervjusvaren, antingen direkt eller på ett mer subtilt sätt. En del av kvinnorna har uppfattat att läkarna testat deras trovärdighet genom placebobehandling.

Exemplen ovan beskriver en diskrepans mellan kvinnornas upplevelser av sitt tillstånd och dess orsaker å den ena sidan och vårdgivarnas bedömningar å den andra. Vårdgivarna kan, enligt intervjuerna, betrakta dem som simulanter, d.v.s. att deras besvär är påhittade eller överdrivna. Detta kan leda till att man känner sig anklagad, vilket kan medföra att man intar en försvarsposition i förhållande till vårdgivare.

Sedan så skulle jagju dåkomma påbehandling och då var det ett helt team då, men det var rena polisförhöret. Tyvärr så var det jag som var den anklagade och dom trodde inte ett ord. (KTS)

Ett ifrågasättande beskrivs även i kontakter med myndigheter. Kontakterna med Försäkringskassan har exempelvis ofta upplevts som problematiska före diagnos erhållits, eftersom sjukdomen ännu inte kunnat verifieras. En del av de intervjuade beskriver att Försäkringskassans personal explicit ifrågasatt deras trovärdighet och därmed deras moraliska förhållningssätt.

Det var en gubbe där [vid Försäkringskas- san] han sa "Ja du kan ju återkomma om du blir påkörd av en buss eller något sådant där, då kommer det ju i ett annat läge». (FM)

Den moraliska karaktären har också ifrågasatts av andra, såsom bekanta, i förhållande till kvinnornas vilja att arbeta, före det att diagnos ställts. Den negativa stereotypering som kvinnorna i sådana fall associeras med, är att tillhöra kategorin arbetsskygga. Många beskriver sig själva som ambitiösa och plikttrogna i förhållande till sitt arbete, vilket innebär en stark motsättning mellan andras uppfattning om deras arbetsmoral och deras egen. Lojaliteten i förhållande till arbetet kan understrykas upprepade gånger under en intervju och många anser sig ha prioriterat arbetet framför den egna hälsan.

Man fick höra på omvägar att de trodde att jag var hemma för att jag inte ville jobba och sådana där saker. Och jag menar, känner de det, och så vet de att jag har jobbat jättemycket, och haft en mycket stor sjuknärvaro på mitt jobb. Jag har ju ofta varit där [vid viktiga tillfällen] med 39 graders feber och penicillin och jag har ofta varit på jobbet fast jag har varit sjuk. (KTS)

Några av de intervjuade har dock inte upplevt sig bli ifrågasatta. En av dessa kvinnor anser att detta beror på att hon faktiskt har synliga yttre tecken på sjukdom.

\section{Psykologiseringavorsaker och symtom}

Som särskilt stigmatiserande beskrivs 
sådana händelser då vårdgivare tillskrivit psykologiska orsaker till kvinnors problem med hälsan. Detta sker enligt intervjuerna framför allt före diagnos har ställts, men även därefter. Den negativa stereotypering som det här är fråga om är att bli betraktad som psykiskt sjuk. Läkarna övergår, enligt kvinnors uppfattning, till att söka psykiska eller psykologiska orsaksförklaringar när objektiva fynd som kan verifiera en fysisk sjukdom inte finns. En del av de intervjuade anser att vissa läkare på förhand, utan att ha gjort ordentliga undersökningar, tagit anamnes eller på annat sätt försökt ta reda på problematiken, har klassat besvären som overkliga/oriktiga eller psykiskt betingade. Psykologisering av besvären innebär ofta en motsättning i förhållande till kvinnornas egen bild av problematiken eftersom de själva inte utesluter fysiska orsaker. En konsekvens av detta är att en del av kvinnorna ifrågasätter läkarnas professionalitet.

De här så kallade experterna man har varit hos, de har inte varit trevliga alls. För när de liksom inte kan göra någonting då kliver de hela tiden på att det är psykiskt, det är psykiskt, det ärpsykiskt. (FM)

Ibland remitteras kvinnorna vidare av läkarna till en psykiatrisk klinik eller uppmanas att söka psykologkontakt. Läkare kan också föreslå antidepressiva läkemedel, vilket flera av de intervjuade upplevt kränkande. En del har känt sig tvingade till att konsultera en psykiater för att kunna bli sjukskrivna och erhålla sjukersättning. Detta kan medföra att man måste simulera psykiska problem för att få behålla sjuk- bidraget eller bli sjukskriven. En kvinna beskriver att hon som en konsekvens av ett sådant agerande känner sig «bespottad, smutsig och äcklig" efteråt.

Psykologisering av kvinnornas besvär kan leda till att det stigma som de tidigare försökt att värja sig mot integreras i identiteten som reellt. Att vårdgivare tolkar besvären som psykiskt betingade kan alltså leda till att den drabbade anammar den tillskrivna identiteten.

Det är en sjukgymnast som är utbildad för att ta hand om psykiskt störda patienter också, så det är ganska bra. Jag har börjat där. (KTS)

Den avvikande status som kvinnan kan känna sig behäftad med kan innebära att hon blir särskilt observant på andra människors reaktioner. Detta kan bidra till att kvinnorna utvecklar en situationsmedvetenhet, eftersom de i förväg måste försöka bedöma och föregripa det intryck de gör i olika situationer. Intervjusvaren visar att kvinnorna efterhand börjar förvänta sig vissa reaktioner från omgivningen och ibland också förutser dem innan de inträffat. Analysen visar att kvinnorna aktivt tolkar in andras reaktioner och kan «läsa aV« när vårdgivaren börjar psykologisera besvären, utan att denne uttrycker detta explicit.

Dummare än så är jag inte att jag förstår, när det liksom underförstått det att är nog säkert nervöst betingat på något sätt. (KTS)

Här måste dock också påpekas att det finns ett avvikande mönster i materialet. Det 
finns också de som upplever att läkarna medikaliserar deras besvär när de hellre skulle vilja ha en diskussion om psykologiska orsaker.

\section{Diagnosens dubbla innebörder}

Att erhålla en diagnos har dubbla innebörder för kvinnorna. Diagnosen har en stor betydelse eftersom den ger legitimitet för besvären. Samtidigt har diagnosens karaktär och benämning en viss betydelse för stigmatisering, eftersom andra människors kunskap om och inställning till diagnoserna har betydelse för hur kvinnorna bemöts. Kvinnorna anser att beteckningen kroniskt trötthetssyndrom är missvisande, eftersom trötthet är ett allmänt ord, vilket kan bidra till att besvären bagatelliseras och marginaliseras av t. ex. vänner och bekanta. Dessutom uppfattar kvinnorna att andra människor nedvärderar fibromyalgi som en kvinnosjukdom.

Kvinnornas tolkning om vårdgivares attityd avseende diagnoserna är att en del vårdgivare anser att diagnoserna är tveksamma och att de har bristande kunskaper om sjukdomarna. Framför allt diagnosen KTS saknar, enligt de intervjuade, en legitimitet hos vårdgivarna: Det [KTS] är inte en diagnos som är accepterad om den nu ens är känd, men är den känd så är den långt ifrån accepterad. De uttrycker också själva tvivel beträffande sin diagnos.

\section{Strategierför att hantera sin situation}

Analysen ovan har visat att KTS och fibromyalgi är potentiellt stigmatiserande sjukdomar. Att leva med en sådan sjukdom kan innebära att man känner viss oro för att bli utsatt för iscensatt stigma, dvs. att bli behandlad av andra som en icke-fullvärdig människa och bli tillskriven en negativ identitet. Kvinnorna upplever att deras identitet som kroniskt sjuk dominerar och tränger undan andra egenskaper som de har. Det uttrycks en oro för att bli behandlad enbart utifrån denna identitet, vilket kan visa sig genom att andra visar ett alltför stort hänsynstagande eller att man ställs utanför den sociala gemenskapen på grund av sjukdomen. De intervjuade beskriver både situationer då de utsatts för iscensatt stigma, liksom upplevt stigma såsom i citatet nedan.

Vad som oroar mig nu egentligen, det är $j u$ att min omgivning skall ta alltför stor hänsyn, så att de därför tror att jag är inte att räkna med. Det är väl den oro jag har, att man skall tro att jaha, hon har ju fibromyalgi så att hon orkar nog inte, vi frågar inte henne, vi ber inte om de råd vi tidigare har fätt. (FM)

Kvinnorna strävar efter att bli betraktade som fullvärdiga samhällsmedlemmar och accepterade som sådana av andra. Intervjusvaren visar att kvinnorna utvecklar en del strategier för att undvika att bli utsatta för iscensatt stigma.

\section{Undandragande som strategi}

Ett undandragande beskrivs i intervjusvaren framför allt i förhållande till det sociala livet och aktiviteter med bekanta, 
i förhållande till vårdgivare, organiserade aktiviteter och kontakter med den egna patientgruppen.

Undandragande från det sociala livet beskrivs som en strategi för att slippa omgivningens krav och förväntningar på hur man bör vara. Många av de intervjuade beskriver att de till följd av sjukdomen deltar i det sociala livet i mindre utsträckning än tidigare. Framför allt undviker kvinnorna sådana personer som tidigare har visat negativa reaktioner på dem och deras sjukdom. Ett undandragande från en del av det tidigare sociala livet kompenseras ofta med en större intimitet och närhet till utvalda människor, dvs. kan medföra en omorientering i relation till andra.

Ett undandragande från det sociala livet kan också bero på att sådana kontakter och aktiviteter upplevs som fysiskt påfrestande eller att det är svårt att planera in aktiviteter i förväg då tillståndet inte kan förutsägas från den ena dagen till den andra.

De intervjuade beskriver även ett undandragande $i$ förhållande till vårdgivarna, i synnerhet läkarna, framför allt om kvinnorna i tidigare kontakt med läkaren i fråga har upplevt att de blivit ifrågasatta eller på annat sätt kränkta. En strategi som ibland används är att söka olika läkare från en gång till annan i stället för att gå till en och samma läkare. Kvinnorna vill inte bli betraktade som krävande patienter som söker hjälp upprepade gånger. Många ger uttryck för att de tror att läkarna uppfattar dem som problematiska patienter, p.g.a. att de har en oklar symtombild som inte går att åtgärda. En del beskriver att de i stället vänder sig till alternativmedicinska vårdgivare, vilket också kan ses som en form av undandragande. Detta undandragande kan också bero på att man upplever att den traditionella vården inte har något att erbjuda i fråga om behandling och bot.

Ett visst undandragande frän medpatienter beskrivs i intervjusvaren. Flera väljer att inte delta i de aktiviteter som ordnas för dessa patientgrupper. Kvinnorna uttrycker ofta negativa känslor om sina medpatienter som de anser har egenskaper som man inte gärna vill förknippa med sig själv, t.ex. att medpatienterna är alltför fokuserade på sina sjukdomar. Friskidentiteten sätts därmed i bakgrunden och sjukidentiteten i förgrunden. Mötet med dessa människor gör att det blir svårare för kvinnorna att upprätthålla en självbild bortom identiteten som kroniskt sjuk.

Medpatienterna kan dock också uppfattas som sympatiskt inställda medmänniskor hos vilka man kan få stöd och med vilka man kan umgås utan att behöva tänka på den informationskontroll som kan krävas i andra sociala miljöer. En del beskriver att de tillsammans med dessa människor kan känna en samhörighet och få en acceptans för sin situation. I mötet med dessa människor får kvinnorna dessutom en möjlighet att ventilera sådant som rör sjukdomen, vilket annars kan vara svårt att ge uttryck för.

\section{Informationsstyrning som strategi}

Ett tydligt mönster i intervjusvaren är informationsstyrning som en strategi för att undvika stigmatisering. Att inte informera andra om sin sjukdom är möjligt eftersom det ofta inte finns några yttre fysiska tecken 
på sjukdomen. De intervjuade beskriver besvikelse på andra människor, som har viss kännedom om tillståndet men inte helt kan förstå deras lidande. De som tidigare i kontakter med andra har blivit utsatta för iscensatt stigma berättar om sin sjukdom selektivt, till ett fåtal utvalda människor, som bedöms som tillförlitliga.

Kvinnorna delar ofta upp sitt sociala umgänge i en stor grupp människor som de direkt undanhåller information om sjukdomen för och en liten grupp som är välinformerade. De visar m.a.o. olika identiteter för olika människor.

Jag kan erkänna det är flera av mina bekanta som inte vet om att jag har... som jag inte har berättat det för utan dom tror att jag fortfarande jobbar heltid och att allt är som vanligt. [....] Det har hänt situationer när jag har blivit besviken på folk som jag har berättat det för och då har jag känt att jag måste välja vilka jag ska berätta det för. (KTS)

Informationsstyrning sker bl. a. genom att dölja sjukdomen från andra, hålla en frisk fasad utåt och ge en självpresentation enligt andras förväntningar. De intervjuade beskriver att de vid sociala sammankomster ibland spelar upp en identitet som en glad, frisk och normal människa, även om detta skulle leda till fullständig utmattning efteråt. Detta bidrar till att andra antingen är helt ovetande om sjukdomen, eller att andras negativa omdömen om kvinnorna. Därmed kan en tidigare identitet som frisk lättare upprätthållas inför andra. Försök att behålla vissa aspekter av vardagslivet, såsom exempelvis arbetet, beskrivs också som ett sätt att leva så normalt som möjligt. Av den anledningen fortsätter en del att arbeta åtminstone deltid även om det kan innebära att de inte orkar med några aktiviteter utanför arbetstiden. De intervjuade beskriver också att de istället för att vara hemma och kurera sig vid sjukdom försöker att fortsätta med samma aktiviteter som vanligt ända tills det blir ohållbart.

Informationsstyrning handlar också om hur mycket och vad andra människor får kunskap om. Kvinnorna med KTS beskriver exempelvis att de inför bekanta selektivt presenterar symtom som har en större legitimitet, såsom magproblem och halsont, eftersom de anser att det inte hade verkat trovärdigt att skylla på trötthet före diagnos erhållits. De beskriver också att de, särkilt före diagnosen erhållits, ibland undanhållit information om delar av symtombilden även från vårdgivarna eftersom symtomfloran ofta är rik och vag och man inte vill bli betraktad som hypokondriker. En strategi som ibland används för att försöka öka trovärdigheten är att gradvis lämna ut information om de olika symtomen.

Den informationskontroll som beskrivits i intervjuerna sker framför allt före det att en diagnos har erhållits. Efter diagnosticeringen av sjukdomen blir det mer legitimt att berätta om de besvär och symtom som hör till sjukdomen. Men eftersom diagnoserna kan ses som tvivelaktiga och det fortfarande finns litet kunskap om dem, kan det vara svårt att lämna ut information även efter det att en diagnos erhållits, speciellt när det gäller symtom som inte primärt kan kopplas till sjukdomen. 
Skulle jag få ont och behöva åka in för hjärtat t.ex. så skulle inte jag säga att jag var fibropatient, då skulle dom strunta i mig, det tror jag. (FM)

Ett omvänt sätt att hantera situationen är att sprida information om sjukdomen. De intervjuade berättar att de kopierar artiklar som handlar om sjukdomen och lämnar till arbetskamrater, vänner och till den närmaste familjen. De försöker också att uppmuntra andra i sin omgivning att delta i olika informationsmöten som hålls kring sjukdomarna. Syftet med denna strategi är att andra skall förstå vad sjukdomarna innebär. Kvinnorna beskriver att de på ett likartat sätt informerar vårdgivarna om sjukdomen för att på så sätt försöka öka även deras kunskap om och förståelse för patientgruppen.

\section{Diskussion}

Den osäkerhet som finns kring sjukdomarna KTS och fibromyalgi och problemen att diagnostisera sjukdomarna, har enligt vår studie betydelse för risken för stigmatisering i interaktion med andra människor, inte minst vårdgivare. Denna osäkerhet är större före det att sjukdomarna har bekräftats med en diagnos. Det är också ett tydligt mönster i studien att tiden före diagnosen ställts beskrivs av kvinnorna som potentiellt stigmatiserande i kontakten med andra. Diagnosen har en dubbel betydelse för kvinnorna eftersom den å ena sidan i viss mån kan upplevas som stigmatiserande, men å andra sidan även kunna minska den stigmatisering som kvinnorna upplevt före diagnos erhållits. Oftast överväger dock de positiva konsekvenserna med att få en diagnos (jfr. Cooper, 1997). Resultatet visar att det inte finns några stora skillnader mellan de två patientgrupperna avseende stigmapotential före diagnos erhållits. De skillnader som framstår som viktiga i förhållande till stigmapotential handlar främst om de respektive diagnosernas innebörder. I synnerhet fibromyalgi kan av andra människor klassas som en kvinnosjukdom, vilket kan uppfattas som nedvärderande. KTS uppfattas som mer tvivelaktig av kvinnorna själva, liksom av deras sociala omgivning och vårdgivare, vilket bl.a. kan bero på att den diagnosen inte har existerat lika länge som diagnosen fibromyalgi.

Stigmatisering är ett resultat av interaktion med andra och en process, i vilken en individ blir tillskriven en för henne yttre identitet som är kopplad till en negativ stereotypering (Jenkins, 2000, Link \& Phelan, 2001). Den föreliggande studien visade att kvinnorna uppfattade sig ha blivit tillskrivna två sådana yttre identiteter av såväl bekanta, tjänstemän i myndigheter som av vårdgivare. Den ena av dessa tillskrivna identiteter var simulant/arbetsskygg och beskrevs i termer av ett ifrågasättande av realiteten i deras sjukdomssymtom. I och med att deras trovärdighet ifrågasätts kastas även en skugga på deras moraliska karaktär, d.v.s. moraliska förhållningssätt som person. Enligt Goffman (1971) är stigmatiseringsprocessen nära kopplad till moralbegreppet, men detta har ofta förbisetts i andra studier på patientgrupperna. Den andra yttre identitet som kvinnorna tillskrivits är att ha psykiska problem, dvs. en identitet kopplad till negativa stereotyperingar om psykiskt sjuka. Denna identi- 
tetstillskrivning har skett i interaktion med vårdgivare, genom tillskrivning av psykologiska orsaker till besvären. Likartade resultat har visats i framför allt Ware's studie (1992), men också berörts i andra studier (Cooper, 1997, Gullacksen, 1998,).

Båda dessa yttre, tillskrivna identiteter, beskrivs i intervjuerna som identiteter som inte motsvarar ens självbild, d.v.s. den interna identiteten och känslan av vem man är. En sådan diskrepans mellan intern och extern av andra tillskriven identitet har en stor betydelse för en individ, eftersom man vill bli uppfattad och bemött av andra som den person som man känner sig vara (Jenkins, 2000). Att detta är betydelsefullt visas i de strategier som kvinnorna aktivt använder för att undvika risken för att bli tillskrivna sådana identiteter som ökar risken för stigmatisering. Att dra sig undan från en del av det sociala livet, i synnerhet från människor som har bemött dem tidigare på ett negativt sätt och att selektivt informera andra om sjukdomen eller helt dölja den, är tydliga sådana strategier. Kvinnorna vill m.a.o. bli betraktade som fullvärdiga, normala människor och utvecklar olika strategier för att undvika iscensatt stigma genom informationsstyrning/-kontroll (Goffman, 1971) och undandragande. Enligt våra resultat till skillnad från Ware's studier (1992, 1998), utvecklar kvinnorna ett undandragande även i förhållande till vårdgivarna, d.v.s. drar sig för att söka vård och att uppsöka en och samma läkare flera gånger.

Episoder av iscensatt stigma beskrivs relativt ofta av de kvinnor som ingår $\mathrm{i}$ denna studie, men upplevt stigma tycks orsaka mer oro och ett större lidande än iscensatt stigma, vilket även andra studier visat (Scambler, 1984, Scambler \& Hopkins, 1986). Generellt sett orsakar stigma ett stort lidande för de drabbade såsom oro, tvivel, skam och en försämrad självkänsla (jfr. Jones et al. 1984, Lazare, 1987). Här bör dock noteras att även om kvinnorna beskriver episoder av iscensatt stigma, och oro för stigmatisering, är det ett undantag att ha inkorporerat den stigmatiserande identiteten som sin självbild. Studien visar alltså framför allt att båda sjukdomarna är potentiellt stigmatiserande på grund av hur de uppfattas av andra och hur vårdgivare agerar före diagnosen ställts, men att kvinnorna aktivt värjer sig mot stigmatisering. Det är alltså bara undantagsvis som fullständig stigmatisering beskrivits i intervjuerna.

Vikten av en tidig diagnosticering av sjukdomarna är uppenbar. Det som är centralt i denna studie, och som inte kunnat utläsas från andra studier, är att fokus förändras vid diagnosen, från de drabbade som personer till att istället handla om diagnosens innebörder och riktighet, vilket inte upplevs lika stigmatiserande.

Avslutningsvis vill vi kort kommentera de implikationer studiens resultat har i förhållande till vårdgivare. Denna studie visar att det är viktigt att vårdgivare $\mathrm{i}$ interaktionen med patienter med oklar symtombild utgår från kvinnornas subjektiva uppfattningar och tar deras symtom på allvar. Patienten har förväntningar på att vårdgivaren skall respektera bilden av hur hon önskar framställa sig själv och sina besvär och ta detta på allvar (Goffman, 1959). Patientens subjektiva uppfattning om sina besvär är m.a.o. viktig (Malterud, 
1990, Söderström, 1991). Det är alltså viktigt att läkaren inte automatiskt tolkar normala undersökningsvärden som bevis för att det inte finns några fysiska orsaker till besvären (jfr. Ware, 1993).

Den vårdpersonal som patienterna träffar bör uppmärksammas på problematiken kring stigmatisering eftersom ett stigma kan göra kontakten med vårdgivare känsligare. Speciellt de kvinnor som är ensamstående är känsliga för de nya och diskrediterande definitioner av identiteten som de utsätts för speciellt från vårdgivarhåll (Charmaz, 1983). En ökad medvetenhet om stigma, och dess konsekvenser för identiteten, kan även leda till en förståelse för de problem som kan finnas hos dessa patienter vid anpassningen till och accepterandet av sjukdomstillståndet (Williams, 1987). Det är också viktigt att uppmärksamma att sjukomstillståndet kan ge upphov till andra problem, vilka kan vara stigmatiserande, såsom arbetslöshet och ekonomiska problem.

\section{Referenser}

Album, D. (1991) Sykdommers og medisinske spesialiteters prestisje. Nordisk Medicin, 106:8-9, 232-236.

Charmaz, K. (1983) Loss of self: A fundamental form of suffering in the chronically ill. Sociology of Health and Illness, 5:2, 168-95.

Conrad,P.(1987) The experience of illness: Recent and new directions. Research in the Sociology of Health Care, 6, 1-31.

Cooper, L. (1997) Myalgic encephalomyelitis and the medical encounter. Sociology of Health \& Illness, 19, 186-207.

Coyle, J. (1999) Exploring the meaning of "dissatisfaction" with health care: The importance of "personal identity threat". Sociology of Health \& Illness, 21:1, 95-124.

Evengård, B. Schacterle, R.S., \& Komaroff, A.L. (1999) Chronic fatigue syndrome: New insights and old ignorance. Journal of Internal Medicine, 246, 455-469.

Fukuda, K., Straus, S.E., Hickie, I., Sharpe, M.C., Dobbins, J.G., Komaroff, A., \& the international chronic fatigue syndrome study group. (1994) The chronic fatigue syndrome: A com- prehensive approach to its definition and study. Annals of Internal Medicine, 121:12, 953-959.

Glaser, B., \& Strauss, A. (1967) The discovery of Grounded theory. Strategies for qualitative research. Chicago: Aldine de Gruyter.

Goffman, E. (1959) The presentation of self in everyday life. New York: Anchor Books.

Goffman, E. (1971) Stigma: Den avvikandes roll och identitet. Stockholm: Raben \& Sjögren.

Gullacksen, A-C. (1998) När smärtan blir en del av livet. Livsomställning vid kronisk sjukdom och funktionshinder. Helsingborg: Gyllene Snittet. (diss.)

Hellström, O., Bullington, J., Karlsson, G., Lindqvist, P., \& Mattsson, B. (1999) A phenomenological study of fibromyalgia. Patient perspectives. Scandinavian Journal of Primary Health Care, 17, 11-16.

Henriksson, C.M. (1995) Living with continuous muscular pain - patient perspectives. Part I: Encounters and consequences. Scandinavian Journal of Caring Sciences, 9:2, 67-76.

Jenkins R. (2000) Social Identity. Routledge: London. 
Johansson, E.E., Hamberg, K., Lindgren, G., \& Westman, G. (1996) "I've been crying my way«- qualitative analysis of a group of female patients' consultation experiences. Family Practice, 13:6, 498-503.

Jones, E.E., Farina, A., Hastorf, A.H., Markus, H., Miller, D.T., \& Scott, R.A. (1984) Social stigma: The psychology of marked relationships. New York: W.H. Freeman and Company.

Komaroff, A.L. (1994) Clinical presentation and evaluation of fatigue and chronic fatigue syndrome. I: Straus, S.E. (red.), Chronic fatigue syndrome. New York: Marcel Dekker.

Lazare, A. (1987) Shame and humiliation in the medical encounter. Archives of Internal Medicine, 147, 1653-1658.

Link, B.G., \& Phelan, J.C. (2001) Conceptualizing Stigma. Annual Review of Sociology, 27, 363385.

Malterud, K. 1990 Allmennpraktikerens møte med kvinnelige pasienter. Bergen: Tano. (diss)

Närvänen, A.L. (1994) Tids- och rumssociologiska aspekter på stigmatisering och totala institutioner. I: Svensson, T. (red.), Samhälle, psykiatrisk vård och psykisk hälsa, Linköpings universitet.

Nørregaard, J., Bülow, P.M., Prescott, E., Jacobsen, S., \& Danneskiold-Samsøe, B. (1993) A four year follow-up study in fibromyalgia. Relationship to chronic fatigue syndrome. Scandinavian Journal of Reumatology, 22, 35-38.

Olin, R. (1995) Fibromyalgi - ett neuroendokrinologiskt syndrom?. Läkartidningen, 92:8, 755-763.

Scambler, G. (1984) Perceiving and coping with stigmatizing illness. I: Fitzpatrick, R., Hinton, J., Newman, S., Scambler, G., \& Thompson, J. (red.), The experience of illness. London: Tavistock Publications.

Scambler, G., \& Hopkins, A. (1986) Being epileptic: Coming to terms with stigma. Sociology of Health and Illness, 8, 26-43.

Strauss, A., \& Corbin, J. (1990) Basics of qualitative research: Grounded theory procedures and techniques. Newbury Park: Sage Publications.

Söderberg, S. (1999) Women's experiences of living with fibromyalgia: Struggling for dignity. Umeå universitet. (diss)

Söderström, U. (1991) Maktförhållanden i patientläkarrelationen. Socialmedicinsk tidskrift, 68 9-10, 434-437.

Ware, N.C. (1992) Suffering and the social construction of illness: The delegitimation of illness experience in chronic fatigue syndrome. Medical Anthropology Quarterly, 6:4, 347-361.

Ware, N.C. (1993) Society, mind and body in chronic fatigue syndrome: An anthropological view. Ciba Foundation Symposium, 173, 62-82.

Ware, N.C. (1998) Sociomatics and illness course in chronic fatigue syndrome. Psychosomatic Medicine, 60, 394-401.

Williams, S. (1987) Goffman, interactionism, and the management of stigma in everyday life. I: Scambler, G. (red.), Sociological theory and medical sociology. London: Tavistock Publications.

Wolfe, F., Smythe, H.A., Yunus, M.B., Bennett, R.M., Bombardier, C., Goldenberg, D.L., Tugwell, P., Campbell, S.M., Abeles, M., Clark, P., Fam, A.G., Farber, S.J., Fiechtner, J.J., Franklin, C.M., Gatter, R.A., Hamaty, D., Lessard, J., Lichtbroun, A.S., Masi, A.T., McCain, G.A., Reynolds, W.J., Romano, T.J., Russell, J. \& Sheon, R.P. (1990) The American college of rheumatology 1990 criteria for The classification of fibromyalgia. Report of the multicenter criteria committee. Arthritis and Rheumatism, $33,160-72$

Åsbring, P., \& Närvänen, A.-L. (2002) Women's experiences of stigma in relation to chronic fatigue syndrome and fibromyalgia. Qualitative Health Research, 12:2, 148-160.

Åsbring P. (2003) Osäkra "sjukdomar" - dilemman och möjligheter. Kvinnliga "patienters" och läkares erfarenheter av kroniskt trötthetssyndrom och fibromyalgi. Stockholm: Karolinska Institutet. (diss) 


\section{Summary}

\section{Chronic fatigue syndrome (CFS) and fibromyalgia and the risk of being stigmatized}

Chronic fatigue syndrome and fibromyalgia have an elusive aetiology, no clear-cut treatment strategy and are often difficult to diagnose. Therefore they can lead to various dilemmas for the people that are affected. Interviews have been conducted with 25 women with these illnesses (12 with CFS and 13 with fibromyalgia), the aim being to investigate whether they are perceived as stigmatizing and, if so, to examine what strategies the women develop to manage the situation. The findings show that the women primarily experience stigmatization before the diagnosis is set and that the diffuse symptomatology associated with the illnesses were especially important for stigmatization. Stigma included questioning the patients' symptom descriptions, and hence their morality, as well as psychologizing about the cause of their symptoms. The diagnosis in itself could also be stigmatizing. Coping with stigma included both withdrawal and approach strategies depending on the particular circumstances and goals that existed. In addition, information control was an important strategy that was described. 